\title{
Death Taxes In The United States: A Brief History
}

Eddie Metrejean, Georgia Southern University, USA

Cheryl Metrejean, Georgia Southern University, USA

\begin{abstract}
Death taxes have been used in various forms in the United States, from a simple stamp tax to the complex estate tax currently in use. On June 7, 2001, President George W. Bush signed legislation that would abolish the federal estate tax in 2010. This would end a 200 year history of death taxes in the U.S., at least for one year, unless Congress changes that legislation. Experts are still debating whether Congress will take such action. This paper examines the history of death taxes, including stamp taxes, inheritance taxes, and estate taxes, in the U.S. and the reasons that death taxes were enacted. They were usually enacted as revenue raising provisions, but some feel that their potential for redistributing wealth is a better reason for their existence. This paper also examines the current estate tax and why such a tax on the wealthy has had the support of several wealthy and influential individuals.
\end{abstract}

Keywords: Estate tax, gift tax, tax history, death taxes

\section{INTRODUCTION}

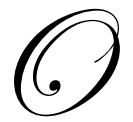

n January 1, 2010, the Federal estate tax will cease to exist for at least one year under current law. Death taxes have been used in various forms, from a simple stamp tax in the late 1790s to the current complex estate tax that exists today. On June 7, 2001, President George W. Bush signed legislation that would abolish the estate tax for 2010 unless Congress acts to change that legislation. Commentators are still at odds over whether Congress will make any such changes.

The reasons for enactment of death taxes have also changed throughout history. Some taxes were enacted to raise revenue during wartime. Other supporters of the death tax claim that such taxes redistribute the wealth of one person to several persons or recipients. The real reason for the existence of death taxes is still in dispute.

This paper provides a history of federal death taxes in the United States. This paper also examines the beginnings of the current estate tax and reasons why a tax on the wealthy has had strong support from wealthy and influential individuals.

\section{AN OVERVIEW OF DEATH TAXES}

Death taxes, or taxes levied at the death of an individual, have been used in several different forms in the U.S. The first death tax was a stamp tax on inventories of decedents, receipts of legacies, shares of personal estates, and probates of wills. (Joint Committee on Taxation, 1999) This stamp tax was only in place for a few years, and its revenue impact was insignificant, even for the late 1700s. (McDaniel et al., 1999)

The next form of the death tax in the United States was an inheritance tax. According to Pechman (1987), an inheritance tax imposes a tax on the privilege of receiving property from the decedent. The basis for the tax is the value of property received from the decedent and is assessed on the recipient of the decedent's property. Inheritance taxes have generally been used sparingly and only for emergency revenue purposes. (Pechman, 1987) Many states, however, use inheritance taxes as one of their regular ongoing sources of revenue. (Pechman, 1987) Among 
developed countries, the inheritance tax seems to be more popular than the estate tax as imposed in the United States. ${ }^{1}$ (Pechman, 1987)

The third and current form of death taxes enacted in the United States is the estate tax. The estate tax has been used intermittently since 1898. An estate tax is assessed on the value of the property left by the decedent. The estate tax can be viewed as a tax on the privilege of transferring property at death. (Pechman, 1987) Early in his presidency, President George W. Bush signed a bill that abolishes the current estate tax by the year 2010; That law, however, includes a provision that if Congress does not act, the estate tax will return in 2011 in the pre-2001 form. Some experts feel that the estate tax will return in 2011, but with less than three years left, pressure is mounting for Congressional action. (Drawbaugh, 2007)

\section{THE HISTORY OF THE ESTATE TAX}

\section{The Beginning}

The first death tax in the U.S. was included in the Stamp Act of 1797. Two years earlier, Thomas Paine wrote two books, The Rights of Man and Agrarian Justice, which proposed and argued that England should enact some type of inheritance tax as a way to redistribute some of the property and wealth that the upper classes in England had accumulated. (Grote, 2000) These arguments may have influenced the U.S. as the Stamp Act of 1797 established a small tax on wills and other documents related to the transfer of property after the death of an individual. The Stamp Act itself was enacted to raise money to finance an undeclared war with France that began in 1794, to help strengthen the U.S. Navy, and to increase the defensive capabilities of the entire U.S. military. (Grote, 2000) This Act began a pattern, which lasted until the early $20^{\text {th }}$ century, of death taxes arising when the U.S. needed to raise revenues for a specific, short-term purpose. Generally, the need for revenue preceded or followed a war, which can be a significant drain on public resources. In the case of the Stamp Act of 1797, the U.S. government was merely trying to strengthen the military as a deterrent and for defensive purposes. (Grote, 2000)

The Stamp Act of 1797's inheritance tax was short-lived. On December 15, 1797 (before the law took effect), Congress passed another law that postponed the enactment of the Stamp Act until June of 1798. Then on April 6, 1802, Congress passed a law abolishing the Stamp Act of 1797. On April 30, 1802, the Office of the Supervisor of Stamps was abolished, and the tax on wills and inheritances were also effectively abolished. (Internal Revenue Service, 1993) Thus the first death tax in the United States was dead.

In January of 1815, Secretary of the Treasury Alexander Dallas recommended to the House Ways and Means Committee that the United States adopt some type of inheritance tax and an income tax. The United States was at war with England and needed to raise revenue to support its war efforts. The House Ways and Means Committee was not very receptive to the idea of more internal revenue taxes and rejected the recommendations. Later that year the war with England ended, and Secretary Dallas' recommendations became unnecessary. (Internal Revenue Service, 1993) The United States had dodged the death tax for a while.

\section{The First Federal Inheritance Tax - The Civil War Era}

In the 1860s the United States again found itself at war, but this time the enemy was from within. The Civil War raged from April 1861 through April 1864. Naturally, the war was very expensive for the United States. On March 3, 1862, the House Ways and Means Committee presented a revenue measure that would purportedly raise nearly $\$ 164$ million, all from the northern states since the southern states had seceded. At least $\$ 1$ million of that amount was to come from an inheritance tax. This inheritance tax included an exemption amount because it was only to be levied on inheritances of personal property over $\$ 1,000$. (Internal Revenue Service, 1993) Once the war was over, Congress recognized that the inheritance tax would be unpopular with the American people. In July of 1866, Congress set the expiration date of the inheritance tax to be some time in 1870, and in May of 1870, the House Ways and Means Committed introduced a bill that would abolish the wartime inheritance tax. This proposal was passed into law as part of the Revenue Act of 1870 on July 14, 1870. (Internal Revenue Service, 1993) 
The internal revenue laws, including the inheritance tax, in the United States at this time were not without challenges. The income tax imposed during the Civil War was challenged in court as a direct tax which is unconstitutional if not apportioned according to the census. In Clark v. Sickel , 4 Am Law T. 141, 5 F.Cas. 981 (1871), the income tax was found to be constitutional in U.S. District Court in Pennsylvania. Three years later, in Scholey v. Rew, 90 U.S. (23 Wall.) 331 (1874), the U.S. Supreme Court determined that the inheritance tax itself was within the Constitution because it was an excise tax rather than a direct tax. In Springer v. U.S., 102 U. S. 586 (1880), the Supreme Court upheld the constitutionality of the Civil War era income tax. This decision is interesting because in 1894, the Wilson Tariff Act stated that property received through inheritance was to be taxed as income. (Pechman, 1987) Then in 1895, the Supreme Court ruled that the income tax was a direct tax and since it was not apportioned according to the census, was not constitutional. (Pollock v. Farmers Loan \& Trust, 157 U. S. 429 (1895)) This decision by the Supreme Court in effect ended the taxation of inheritances as income.

\section{A New Kind Of Death Tax - The Estate Tax}

For several years, the United States had no death tax at all. However, in January 1898, the U.S. government sent the battleship USS Maine to Havana to protect U.S. interests in Cuba because of an uprising against the Spanish government in Cuba. In February1898, the USS Maine was destroyed, and the American public and government blamed the Spanish government. The destruction of the USS Maine was a catalyst for the beginning of the Spanish-American War, and the U.S. found itself preparing for war and needing revenue. Congress enacted a new death tax in 1898 as part of the War Revenue Act of 1898 to help finance the Spanish-American War. This tax was really a combination of an estate tax and an inheritance tax. (McDaniel et al., 1999) This combination tax was short-lived, however, and on April 12, 1902, Congress repealed the war taxes, including the death tax, as a result of decreasing expenditures after the war. (Internal Revenue Service, 1993)

A few years later, President Theodore Roosevelt announced his support of both income and inheritance taxes to Congress. Naturally, most members of Congress did not meet such a proposal with enthusiasm. Up to this time, death taxes had been used for one purpose - to raise revenues, generally in response to a war. But President Roosevelt's proposal for an inheritance tax was based on another motivation. President Roosevelt felt that such a tax would help to redistribute accumulations of wealth. (Grote, 2000) While such a proposal from a president who was fairly wealthy himself seemed unusual, other influential or wealthy individuals throughout history had similar views. For example, Thomas Paine (in the late1700s) and Andrew Carnegie (in the 1890s) both proposed such inheritance taxes as a means of distributing accumulated wealth. (Grote, 2000) More recently, billionaire Warren Buffett has endorsed the estate tax as a means of helping to curb the growth of the "wealth gap". (Drawbaugh, 2007) This topic is covered in more detail later in this paper.

Although President Roosevelt wanted Congress to act on his inheritance tax, no legislation was ever enacted as a result of his proposals. However, Congress did come close at one point. In March of 1909, the House Ways and Means Committee proposed a bill that would reinstate the inheritance tax, but in July of that year, an amendment to that bill removed the inheritance tax provision. (Internal Revenue Service, 1993)

Interestingly, Congress did approve a constitutional amendment to allow an income tax at nearly the same time that they rejected an inheritance tax. (Internal Revenue Service, 1993) Proponents of an income tax finally got their wish on February 25,1913 , when the $16^{\text {th }}$ Amendment was ratified, and the constitutionality of the income tax was clearly established for the first time in the United States.

Not long after the ratification of the $16^{\text {th }}$ Amendment, The United States entered World War I. During this time, the United States derived a vast majority of its tax revenues from tariffs. Naturally, since Europe was at war, imports and exports between the United States and Europe decreased dramatically, along with the associated tariffs that imports brought. Congress again saw the need for additional forms of revenue for financing its domestic programs and another war. On September 9, 1916, the estate tax became a permanent part of the government's revenue sources with the passage of the Revenue Act of 1916. This estate tax was based on the value of the decedent's net estate, which made it a true estate tax and not an inheritance tax. (Internal Revenue Service, 1993) Not everyone was happy with this new estate tax, and in 1921, the Supreme Court was called on to settle the question of the constitutionality of the tax. In New York Trust Co. v. Eisner, 256 U.S. 345 (1921), the Supreme 
Court determined that the estate tax was indeed constitutional. In October of 1925, Secretary of the Treasury Mellon proposed to the House Ways and Means Committee a reduction of taxes and a repeal of the estate taxes. By now, World War I had ended, and President Coolidge felt that the American people should not be required to pay more than necessary for government operations. Secretary Mellon's proposal was not met warmly, and Congress took no action on his proposal. (Internal Revenue Service, 1993) The new estate tax had survived its first two significant tests.

Once the estate tax had been in effect for several years, taxpayers began devising ways to avoid the tax. One method was to simply give all property away just before death, if possible. Congress attempted to stop this scheme with the Revenue Act of 1924 which established a gift tax to recapture some of the tax revenue that was being lost through loopholes in the estate tax. (Pechman, 1987) The Revenue Act of 1926 repealed the gift tax but added a provision that required any gifts transferred within two years of death to be included in the estate of the decedent. However, the Supreme Court, in Heiner v. Donnan, 285 U.S. 312 (1932), found this two-year provision unconstitutional. In response, Congress once again imposed the gift tax in 1932. (McDaniel et al., 1999; Internal Revenue Service, 1993) The reenactment of the gift tax had a twofold effect. First, it closed the loophole that taxpayers were using to avoid paying estate taxes. Second, and more importantly, it gave the government much needed revenues for its Depression era spending programs for the needy. (Grote, 2000)

The estate tax enacted in 1916 set the standard for what the estate tax would be for the next 50 years. Other than rate and exemption changes and several other minor changes, the estate tax remained largely unchanged until 1976. The most significant changes during this period were introduced in 1948. In that year, an estate and gift tax marital deduction and the principle of splitting gifts were added. (Internal Revenue Service, 1993; Grote, 2000) The marital deduction allowed (and still allows) an individual to pass property to a spouse without incurring any taxes. The principle of gift splitting allows a married couple to consider any gift to a third party as being made one-half from each person. This is advantageous when considering the annual exclusion amount, which was introduced in 1932. The annual exclusion allows a donor to exclude a certain amount of donated assets each year for purposes of calculating the gift tax. Currently, a donor can exclude up to $\$ 12,000$ per donee per year and pay no gift tax. With gift splitting, a married couple can gift up to $\$ 24,000$ per donee per year.

\section{A Major Overhaul Of The Estate Tax - A Unified Structure}

In 1976, the face of the estate tax changed dramatically with the Tax Reform Act (TRA) of 1976. TRA of 1976 included provisions that created a single unified rate structure for cumulative lifetime transfers and transfers at death. Included in the estate and gift tax laws was a unified credit that exempted a certain amount of transfers (either lifetime or at death) from being taxable. A generation-skipping tax was also enacted. This provision taxed transfers to beneficiaries two or more generations younger than the party making the transfers. Under the generation skipping provisions, these transfers were taxed at the unified transfer tax rate just as if the "skipped" generation had made the transfer. Another significant provision in TRA of 1976 for many taxpayers was the provision that required recipients of property to assume a carryover basis in that property. Such a provision required that all of the property's appreciation was to be taxed upon disposition of the property by the recipient even though he or she might have held the property for only a short period of time in which the property appreciated little. In effect, the recipient got the same basis in the property that the decedent had. This resulted in a situation where the recipient was treated as if he or she had originally purchased the assets, and taxpayers could have paid large amounts of income tax on capital gains when they did not hold the property while it was increasing in value. (Joint Committee on Taxation, 1999) In 1980, these carryover provisions were repealed and replaced with "stepped-up basis" provisions that had existed before TRA of $1976 .{ }^{2}$

Another major milestone in the history of the estate tax was the Economic Recovery Tax Act of 1981. In this Act, Congress raised the value of exempt property to $\$ 600,000$. This change significantly reduced the number of taxpayers subject to the estate tax. More importantly, however, the 1981 Act created an unlimited marital deduction that allowed an unlimited amount of property to be transferred to a surviving spouse without taxation. Such a provision meant that an individual could die and leave everything to his or her spouse and pay no estate tax. (Joint Committee on Taxation, 1999) Of course, without proper planning, the surviving spouse would have a much larger estate that would be subject to the estate tax. 
In more recent history, the Taxpayer Relief Act of 1997 increased the exemption equivalent of the unified credit to $\$ 1,000,000$. However this increase was to be phased in over eight years and take full effect in 2006. (McDaniel et al., 1999; Grote, 2000; Joint Committee on Taxation, 1999)

On June 7, 2001, President George W. Bush signed the Economic Growth and Tax Relief Reconciliation Act of 2001 (the 2001 Act). This act "repeals" federal estate, gift, and generation-skipping taxes after 2009, but the Act includes a "sunset" provision. This sunset provision means that all of the provisions of the 2001 Act would expire after December 31, 2010, and the rules previously in effect would be reinstated. Many of the provisions of the Act have phase in periods. To add to the confusion, Congress can repeal or amend the 2001 Act before it goes completely into effect. (Ernst \& Young, 2001) In light of the sunset provision, it is entirely possible that the estate tax could disappear in 2010 only to reappear the next year using the pre-2001 rules. Only time will tell.

\section{UNLIKELY SUPPORTERS OF THE ESTATE TAX}

Many supporters of the estate tax claim that the estate tax was enacted to help prevent the accumulation of large amounts of wealth. However, the history of the estate tax and statistics gathered over the years show that before the 1930s, the estate tax existed merely for revenue generation. When the United States needed revenue to finance wars, an inheritance or estate tax was enacted. When the wars ended, the death taxes were repealed.

Several very influential individuals, past and present, have come forward in support of an estate tax as a means of breaking up accumulations of wealth and redistributing that wealth to those who need it. Thomas Paine, who is probably best known for writing a book that is often credited with inciting the Colonies to declare their independence from England, was one of the first known supporters of an estate tax. (Grote, 2000) In his book The Rights of Man, Paine suggested that England should have an inheritance tax to balance out the unfair accumulation of real property by wealthy individuals. Even though Paine suggested an inheritance tax for England, his works were certainly influential in the United States. (Grote, 2000) Thomas Paine was known as a man who distrusted government and hated taxes, but he supported the redistribution of wealth. He strongly favored taxing the wealthy to help redistribute wealth to the less fortunate. He felt that the wealthy should pay into a national fund that would have resembled an early version of today's Social Security system. (Grote, 2000)

About 100 years later, Andrew Carnegie made known his opinions on the accumulation of wealth. In his book The Gospel of Wealth, Carnegie strongly supported some kind of estate tax. Carnegie felt that a person had three options for distributing his or her wealth. One could leave the wealth to decedents, give the wealth to the government for public purposes, or give the wealth to charitable organizations of his or her choice. Carnegie abhorred the first option, tolerated the second option, and encouraged the third option. (Carnegie, 1962; Grote, 2000) In fact, Andrew Carnegie left only about $10 \%$ of his wealth to his family, choosing instead to give most of his wealth away during his lifetime. Carnegie supported an estate or inheritance tax because he felt that an unintended benefit was to induce wealthy individuals to "administer" their wealth during their lifetimes rather than simply leaving it to their families. Carnegie's reasons for such actions are his belief that if a person receives a large inheritance, he or she becomes less of a contributor to society and wastes his or her talents. (Carnegie, 1962)

Interestingly, both the popular press and academic researchers have examined the topic of inheritance and talent. For example, Kirkland (1986) surveyed several multimillionaires and found that $20 \%$ of these wealthy individuals said that their heirs would be better off without large inheritances, and almost half of those surveyed planned to split their fortunes almost equally among family and charities. (Kirkland, 1986) Further, a study performed by Holtz-Eakin et al. (1993) found that there seemed to be an inverse relationship between the size of a bequest and the labor force participation of the person receiving the bequest. In other words, the more a person received as an inheritance, the less that person was inclined to work. Such findings seem to support the view that breaking up accumulations of wealth via some type of death tax might positively affect productivity.

One of the more improbable supporters of an estate tax was President Theodore Roosevelt. In the early 1900s, President Roosevelt suggested that Congress should reinstate an estate tax to help with a redistribution of accumulated wealth. However, Roosevelt felt that wealthy individuals had an obligation to the government rather than to charities themselves, which was in contrast to Carnegie's opinion that the wealthy had an obligation to the 
charities. (Grote, 2000) Roosevelt was never successful in his attempt to enact an estate tax, however, and as stated above, an estate tax was not enacted until 1916 when the United States needed revenue to counteract decreasing tariffs on imports from Europe as a result of World War I.

More recently, William Gates, Sr., the father of Microsoft Corporation's Bill Gates, helped to start a campaign to preserve the estate tax. In 2001, nearly 1,000 wealthy individuals whose estates would be subject to estate taxes signed a petition started by Mr. Gates to keep the estate tax. Mr. Gates feels that more of the revenue that the government collects should come from the rich. His proposal is that the revenue should come in the form of an estate tax on large estates. He also feels that people who receive large inheritance are not very productive members of society because they have never had to work for anything. (Grote, 2001) These comments are quite interesting since they come from the father of the wealthiest individual in the United States. (Drawbaugh, 2007)

In 2007, billionaire Warren Buffett endorsed the estate tax, arguing that the increasing wealth gap threatens the equality of opportunity in this country. He argues that recent tax legislation benefits the wealthy and widens the gap between the wealthy and the middle class. Mr. Buffett has also recently announced that he plans to donate most of his wealth to charity before his death rather than leave it to his family. (Drawbaugh 2007)

\section{CONCLUSION}

The death tax has been around in American history in several forms for over 200 years. From a simple stamp tax in 1797 on the probate of wills and on documents to transfer property to the current complex estate tax laws, death taxes have played a significant part in tax history. While tax revenues from estate and gift taxes might be an insignificant percentage of the total amount of tax collected, even this small percentage equaled approximately $\$ 26$ billion for fiscal year 2007. (Internal Revenue Service, 2008) Supporters claim that the estate tax has been a means of redistributing accumulated wealth. Several of these supporters have been some of the wealthiest and most influential individuals in U.S. history. As such, they support more taxes on themselves.

History has shown, however, that death taxes, in the form of both inheritance taxes and estate taxes, have been enacted several times merely as a source of revenue for the federal government, usually in a time of war. Once these wars were over, the inheritance or death taxes disappeared. This was the case until 1916 when an estate tax was enacted to help counteract the loss of revenues that existed before World War I. Since that time, the estate tax has been a permanent fixture in U.S. tax law. The estate tax remained fairly static, except for rate and exemption changes, from 1926 until 1976. In the latter year, Congress made wholesale changes to the estate and gift tax system, which resulted in the current unified system. More recently, President George W. Bush signed the Economic Growth and Tax Relief Reconciliation Act of 2001, which "repeals" the estate tax in 2010. After 2010, if Congress does not act, the estate tax will reappear automatically in 2011. Many experts feel that a full repeal of the estate tax will not occur. Congress has waited longer than some expected to address the repeal of the estate tax. Only time will tell what the future of the estate tax will be, and that time is now relatively short.

\section{AUTHOR INFORMATION}

Eddie Metrejean, Ph.D, CPA, CFE, is an Assistant Professor of Accounting at Georgia Southern University. After completing his bachelor's degree in Accounting from the University of Louisiana at Lafayette, Dr. Metrejean worked for a large regional public accounting firm as an auditor and then as a corporate controller for a group of small companies. Dr. Metrejean received a Master of Taxation degree in 1997 and a Ph.D. in Accounting in 2004, both from the University of Mississippi. Dr. Metrejean has published a variety of articles in accounting, taxation, and business journals. His teaching and research interests are primarily in auditing, accounting information systems, and taxation.

Cheryl Metrejean, Ph.D, CPA, CFE is an Assistant Professor of Accounting at Georgia Southern University. Dr. Metrejean received her Bachelor's degree from the University of Louisiana at Lafayette, her Master of Accountancy degree from the University of North Carolina at Chapel Hill and her Ph.D. in accounting from Texas A\&M University. Dr. Metrejean worked as a senior tax accountant at Ernst \& Young in Houston, Texas and Washington, D.C. Dr. Metrejean has published a variety of education and taxation articles various taxation, accounting, and business journals. She is on the editorial board for the ATA Journal of Legal Tax Research. 


\section{END NOTES}

${ }^{1}$ In most countries that impose estate, inheritance, and gift taxes, the revenues from such taxes are only a small part of the country's total tax revenues. For example, in 2005 , only $.89 \%$ of all tax revenues in the U.S. came from estate and gift taxes. Only Belgium (1.30\%), France (1.19\%), Japan (1.14\%), and Korea (.91\%) rely more heavily on death taxes than the U.S. (Joint Committee on Taxation, 2007)

${ }^{2}$ With a stepped up basis, the recipient's basis in the property become the fair market value at the date of death of the decedent. Fair market value is usually significantly higher than the original basis in the property. Such a provision is a significant advantage especially when property has been held for a long period of time and has increased in value substantially. The step up in basis allows the recipient of the property to be taxed only on appreciation while in his or her possession, i.e., post death appreciation. In addition, it removes the potential recordkeeping issues associated with finding a decedent's basis in some properties after death.

\section{REFERENCES}

1. Carnegie, Andrew. The Gospel of Wealth and Other Timely Essays. Cambridge, MA: The Belknap Press of Harvard University Press, 1962.

2. $\quad$ Clark v. Sickel, 4 Am Law T. 141, 5 F.Cas. 981, 1871.

3. Drawbaugh, Kevin. Buffett Backs Estate Tax, Decries Wealth Gap. Accessed on July 5, 2008 at www.reuters.com, November 14, 2007.

4. Ernst \& Young. The Economic Growth and Tax Relief Reconciliation Act of 2001. Financial Planning Reporter. Vol. 14, No. 2, pp. 1-12, 2001.

5. Gross, Daniel. The War Tax: Large Estates Should Pay Their Share. American Prospect Online. November $16,2001$.

6. Grote, Jim. Mt. Rushmore and a History of the Estate Tax. Planned Giving Today. Vol. 10, No. 6, pp. 1, $8-9,2000$.

7. Grote, Jim. Reflections on the Estate Tax and Philanthropy: An Interview with William Gates, Sr. Planned Giving Today. Vol. 11, No. 11, pp. 1, 7, 2001.

8. $\quad$ Heiner v. Donnan, 285 U.S. 312, 1932.

9. Holtz-Eakin, Douglas, David Joulfaian, and Harvey S. Rosen. 1993. The Carnegie Conjecture: Some Empirical Evidence. The Quarterly Journal of Economics. Vol. 108, No. 2, pp. 413-436.

10. Internal Revenue Service. IRS Historical Fact Book: A Chronology. Washington, D.C.: Department of the Treasury, 1993.

11. Internal Revenue Service. Internal Revenue Service Data Book, 2007, Publication 55B. Washington, D.C.: Department of the Treasury, 2008.

12. Joint Committee on Taxation. Present Law and Background on Federal Tax Provisions Relating to Retirement Savings Incentives, Health and Long-Term Care, and Estate and Gift Taxes (JCX-29-99). June $15,1999$.

13. Joint Committee on Taxation. History, Present Law, and Analysis of the Federal Wealth Transfer Tax System (JCX-108-07). November 13, 2007.

14. Kirkland, Richard I., Jr. Should You Leave it All to the Children? Fortune. Vol. 136, No. 7, pp. 18-26, 1986.

15. Lav, Iris J., and Joel Friedman. Estate Tax Repeal: A Costly Windfall for the Wealthiest Americans. Center on Budget and Policy Priorities. Access on July 3, 2008 at http://www.cbpp.org/5-25-00tax.pdf, 2001.

16. McDaniel, Paul R., James R. Repetti, and Paul R. Caron. McDaniel, Repetti, and Caron's Wealth Transfer Taxation, Fourth Edition. New York, NY: Foundation Press, 1999.

17. New York Trust Co. v. Eisner, 256 U.S. 345, 1921.

18. Pechman, Joseph A. Federal Tax Policy, Fifth Edition. Washington, D.C.: The Brookings Institution, 1987.

19. Pollock v. Farmers Loan \& Trust, 157 U. S. 429, 1895.

20. $\quad$ Scholey v. Rew, 90 U.S. (23 Wall.) 331, 1874.

21. Springer v. U.S., 102 U. S. 586, 1880. 


\section{NOTES}

